Article

\title{
Application of Preparative High-Speed Counter-Current Chromatography for the Separation of Two Alkaloids from the Roots of Tabernaemontana catharinensis (Apocynaceae)
}

\author{
Milena S. Gonçalves, Ivo J. Curcino Vieira *, Rodrigo R. Oliveira and Raimundo Braz-Filho \\ Laboratório de Ciências Químicas, Universidade Estadual do Norte Fluminense Darcy Ribeiro, \\ 28013-602, Campos dos Goytacazes, Rio de Janeiro, Brazil \\ * Author to whom correspondence should be addressed; E-Mail: curcino@uenf.br; \\ Tel.: +55-22-27397234; Fax: +55-22-27397248.
}

Received: 28 June 2011; in revised form: 16 August 2011 / Accepted: 31 August 2011 /

Published: 2 September 2011

\begin{abstract}
The methanolic extract of Tabernaemontana catharinensis (Apocynaceae) roots, which contains alkaloids with several biological activities, was separated on a preparative scale using high-speed counter-current chromatography. The optimum solvent system was found to be a mixture of $\mathrm{CHCl}_{3}-\mathrm{MeOH}-\mathrm{H}_{2} \mathrm{O}[5: 10: 6(v / v / v)]$ and led to a successful separation of two monoterpenic indole alkaloids, voachalotine (1) and 12-methoxy- $N_{\mathrm{b}^{-}}$ methylvoachalotine (2) in approximately 4.0 hours. The alkaloids were all isolated at purities over $95 \%$, and their structures were established on the basis of spectroscopic methods, including $1 \mathrm{D}$ and 2D NMR and EI/MS.
\end{abstract}

Keywords: counter-current chromatography; Tabernaemontana catharinensis; alkaloids

\section{Introduction}

The genus Tabernaemontana includes about 110 species widespread in the pantropical regions, and these species are rich in alkaloids [1-4], mostly of the monoterpenic indole type, revealing a considerable variety of carbon skeletons and novel biological activities [5].

Tabernaemontana catharinensis A. DC. (syn. Peschiera catharinensis A. DC. Miers) (Apocynaceae), popularly known as 'milkweed', occurs in Argentina, Paraguay, Bolivia and southern Brazil. The species has also been named T. affinis, T. australis and T. hilariana [1]. The alkaloids and 
alkaloid-containing extracts from the species show diverse biological activities: antitumoral, antiinflammatory, analgesic [6], anticrotalic and antitumoral [7], antioxidant and antimycobacterial [8], trypanocidal [9] and antileishmanial activities [10,11].

Preliminary phytochemical investigation using classical chromatographic methods (adsorption column chromatography) led to the detection of alkaloids with acetylcholinesterase inhibitory properties in the polar extracts of the roots of $T$. catharinensis [12]. The separation of compounds present in a crude extract is often performed by repeated adsorption column chromatography. In our case, we investigate mainly polar extracts containing alkaloids compounds, which can be degraded because of the acidic nature of the silica gel. To overcome this problem, the use of high-speed countercurrent chromatography (HSCCC) that does not employ a solid-phase support and thus there is no irreversible adsorption associated with the solid supports, can be an alternative to the direct application of crude extracts and provide excellent recovery of the compounds [13]. This method has been successfully applied to the analysis and separation of various natural products $[14,15]$. One of the advantages of HSCCC in relation to others liquid-liquid chromatography techniques are the possibility of shorter separation times. The main purpose of this contribution was to study the purification on a preparative scale of the two main monoterpenic indole alkaloids, voachalotine (1) and 12-methoxy- $N_{\mathrm{b}^{-}}$ methylvoachalotine (2), from $T$. catharinensis by HSCCC.

\section{Experimental}

\subsection{Reagents}

All organic solvents used for HSCCC were of analytical grade and purchased from Synth (São Paulo, Brazil). Water was purified by Milli-Q system (Millipore, Bedford, MA, USA). voachalotine (1) and 12-methoxy- $N_{\mathrm{b}}$-methylvoachalotine (2) standards were obtained in our Laboratory of Chemical Sciences (UENF, Brazil) by column chromatography. The identity of the isolated alkaloids were confirmed by their spectroscopic properties $\left({ }^{1} \mathrm{H}\right.$ - and $\left.{ }^{13} \mathrm{C}-\mathrm{NMR}\right)$. NMR spectra were obtained on a Brüker Advance II 9.4 T instrument with $\mathrm{CDCl}_{3}(0.1 \% \mathrm{TMS})$ as solvent. UV spectra were recorded on a Shimadzu model 1800 Shimadzu software UV - PROBE and IR data on a model IR AFFINITY, SHIMADZU and GC/MS analysis were carried out on a Shimadzu CG/EM-QP-5050 SHIMADZU, at $70 \mathrm{eV}$ (column DB5, $30 \mathrm{~m}$ ).

\subsection{Preparation of Crude Sample and Sample Solution}

Roots $(2.8 \mathrm{Kg})$ of $T$. catharinensis were collected at Araguari, Minas Gerais State, Brazil and authenticated by Luiza S. Kinoshita. A voucher specimen (No. UEC117862) was deposited at the Herbarium of the Unicamp University, Campinas, São Paulo State, Brazil. The air-dried and powdered roots $(1.8 \mathrm{Kg})$ were exhaustively extracted (three times) with methanol $(3 \mathrm{~L})$ at room temperature (3 days). Solvents were evaporated under reduced pressure affording the crude $\mathrm{MeOH}$ extract (63.2 g). The $\mathrm{MeOH}$ extract was submitted to silica gel column chromatography affording 16 fractions (1-16). An aliquot of fraction $12(0.18 \mathrm{~g})$ containing of mixture of alkaloids $\mathbf{1}$ and $\mathbf{2}$ was dissolved in $5 \mathrm{~mL}$ of a mixture consisting of $2.5 \mathrm{~mL}$ lower phase $+2.5 \mathrm{~mL}$ upper phase of the solvent system $\mathrm{CHCl}_{3}-\mathrm{MeOH}-\mathrm{H}_{2} \mathrm{O}(5: 10: 6(v / v / v))$. 


\subsection{Apparatus}

HSCCC was carried out using a Dynamic Extractions Ltd. Model Spectrum-1000 mini high-speed counter-current chromatography unit (Berkshire, UK), containing a self-balancing three-coil centrifuge rotor equipped two preparative multiplayer coils with a total capacity of $142 \mathrm{~mL}$, the internal diameter of PTFE tubing was $1.6 \mathrm{~mm}$. The $\beta$-value range varied from 0.52 at internal to 0.86 at the external terminal. The speed was adjusted with a controller to an optimum speed of 1,200 rpm. The flow rate was controlled with a Knauer Smartline-1000 constant flow pump with a capacity of $5 \mathrm{~mL} / \mathrm{min}$. The sample was injected via a P.C. injection module with a $5 \mathrm{~mL}$ sample injection loop. The coiled column was entirely filled with the stationary phase (upper phase). Then the apparatus was rotated forward at $1,200 \mathrm{rpm}$, while the mobile phase (lower phase) was pumped into the column in a head to tail direction at a flow rate of $1.5 \mathrm{~mL} / \mathrm{min}$. After the mobile phase front emerged, $5 \mathrm{~mL}$ of the sample solution containing the sample of fraction 12 of the methanolic extract was injected at a flow rate $1.5 \mathrm{~mL} / \mathrm{min}$. We collected 220 fractions of $4 \mathrm{~mL}$ each with a Büchi fraction collector C-660, in approximately $4 \mathrm{~h}$, while monitoring with a UV-Knauer detector at $300 \mathrm{~nm}$.

\subsection{Preparation of Two-Phases Solvent System}

The solvent system composed of $\mathrm{CHCl}_{3}-\mathrm{MeOH}-\mathrm{H}_{2} \mathrm{O}(5: 10: 6(v / v / v))$ was throughly equilibrated in a separatory funnel at room temperature and two phases separated shortly before use.

\subsection{Analyses of the Alkaloids by TLC}

An aliquot of fraction 12 and the collected 214 fractions were analyzed using silica gel on aluminium TLC sheets $(20 \mathrm{~cm} \times 20 \mathrm{~cm}$, Merck $)$ developed with a solvent mixture composed of $\mathrm{CH}_{2} \mathrm{Cl}_{2}-\mathrm{MeOH}[9: 1(v / v)]$. The spots on the TLC sheets were observed under a UV lamp (254 nm) and revealed with sulfuric vanilin and Dragendorff reagents. Fractions of similar retention factors $\left(R_{\mathrm{F}}\right)$ were combined and subimetted from the analyses NMR.

\subsection{Structural Identification of the Alkaloids}

The spectral data of the two alkaloids are as given below:

Voachalotine (1): ${ }^{1} \mathrm{H}-\mathrm{NMR}\left(400 \mathrm{MHz}, \delta_{\mathrm{H}}\right.$ in ppm): $\delta_{\mathrm{H}} 7.50(1 \mathrm{H}$, br d, $J=7.6 \mathrm{~Hz}, \mathrm{H}-9), 7.21(1 \mathrm{H}, \mathrm{br} \mathrm{d}$, $J=8.3$ and $1.1 \mathrm{~Hz}, \mathrm{H}-11), 7.11(1 \mathrm{H}$, br $\mathrm{d}, J=7.9$ and $1.4 \mathrm{~Hz}, \mathrm{H}-10), 7.30(1 \mathrm{H}, \mathrm{br} \mathrm{d}, J=8.3 \mathrm{~Hz}$, $\mathrm{H}-12), 1.63(3 \mathrm{H}, \mathrm{d}, J=7.9 \mathrm{~Hz}, 3 \mathrm{H}-18), 5.34(1 \mathrm{H}, \mathrm{tq}, J=6.6$ and $2.0 \mathrm{~Hz}, \mathrm{H}-19), 4.22(1 \mathrm{H}, \mathrm{dd}, J=9.9$ and $4.1 \mathrm{~Hz}, \mathrm{H}-3), 4.33(1 \mathrm{H}, \mathrm{d}, J=6.0 \mathrm{~Hz}, \mathrm{H}-5), 3.25(1 \mathrm{H}$, br t, $J=3.0 \mathrm{~Hz}, \mathrm{H}-15), 3.15(1 \mathrm{H}$, dd, $J=15.6$ and $6.3 \mathrm{~Hz}, \mathrm{H}-6 \mathrm{a}), 2.99(1 \mathrm{H}$, br d, $J=15.6 \mathrm{~Hz}, \mathrm{H}-6 \mathrm{~b}), 2.02(1 \mathrm{H}$, ddd, $J=12.6,9.7$ and $2.6 \mathrm{~Hz}, \mathrm{H}-14 \mathrm{a}), 1.83$ (1H, td, $J=12.6$ and $3.6 \mathrm{~Hz}, \mathrm{H}-14 \mathrm{~b}), 3.71(1 \mathrm{H}, \mathrm{br} \mathrm{d}, J=11.7 \mathrm{~Hz}, \mathrm{H}-17 \mathrm{a}), 3.62$ $(1 \mathrm{H}, \mathrm{d}, J=11.7 \mathrm{~Hz}, \mathrm{H}-17 \mathrm{~b}), 3.60(2 \mathrm{H}, \mathrm{m}, \mathrm{H}-21 \mathrm{a}$ and $\mathrm{H}-21 \mathrm{~b}), 3.64(3 \mathrm{H}, \mathrm{s}, \mathrm{MeN}-1), 3.76(3 \mathrm{H}, \mathrm{s}$, MeO-22). ${ }^{13} \mathrm{C}-\mathrm{NMR}\left(100 \mathrm{MHz}, \delta_{\mathrm{C}}\right.$ in ppm): $\delta_{\mathrm{C}} 137.4$ (C-2), 105.0 (C-7), 126.0 (C-8), 138.0 (C-13), 53.4 (C-16), 137.5 (C-20), 176.4 (C-22), 48.0 (CH-3), 53.8 (CH-5), 118.3 (CH-9), 119.0 (CH-10), 121.2 (CH-11), 108.9 (CH-12), 29.9 (CH-15), 116.5 (CH-19), $22.3\left(\mathrm{CH}_{2}-6\right), 28.4\left(\mathrm{CH}_{2}-14\right), 63.1$ $\left(\mathrm{CH}_{2}-17\right), 54.0\left(\mathrm{CH}_{2}-21\right), 12.9\left(\mathrm{CH}_{3}-18\right), 30.3\left(\mathrm{CH}_{3} \mathrm{~N}-1\right), 52.3\left(\mathrm{CH}_{3} \mathrm{O}-22\right)$. 
12-Methoxy- $N_{b}$-methylvoachalotine (2): ${ }^{1} \mathrm{H}-\mathrm{NMR}\left(400 \mathrm{MHz}, \delta_{\mathrm{H}}\right.$ in ppm): $\delta_{\mathrm{H}} 6.28(1 \mathrm{H}, \mathrm{br} \mathrm{d}, J=11.1 \mathrm{~Hz}$, H-3), 4.96 (1H, d, $J=6.4$ Hz, H-5), 7.27 (1H, d, $J=7.0 \mathrm{~Hz}, \mathrm{H}-9), 7.25$ (1H, t, $J=7.0 \mathrm{~Hz}, \mathrm{H}-10), 6.93$ $(1 \mathrm{H}, \mathrm{d}, J=7.0 \mathrm{~Hz}, \mathrm{H}-11), 3.31$ (1H, m, H-15), 5.60 (1H, q, $J=6.4 \mathrm{~Hz}, \mathrm{H}-19), 3.96$ (1H, m, H-6a), $3.30(1 \mathrm{H}, \mathrm{m}, \mathrm{H}-6 \mathrm{~b}), 2.40$ (1H, m, H-14a), 1.86 (1H, m, H-14b), $3.78(1 \mathrm{H}, \mathrm{m}, \mathrm{H}-17 \mathrm{a}), 3.13(1 \mathrm{H}, \mathrm{m}$, H-17b), 5.31 (1H, br d, $J=15.8 \mathrm{~Hz}, \mathrm{H}-21 \mathrm{a}), 3.90$ (1H, m, H-21b), 1.82 (3H, d, $J=6.4 \mathrm{~Hz}, \mathrm{H}-18), 4.18$ $(3 \mathrm{H}, \mathrm{s}, \mathrm{MeN}-1), 3.35$ (3H, s, MeN-4), 4.18 (3H, s, MeO-12), 3.99 (3H, s, MeO-22). ${ }^{13} \mathrm{C}-\mathrm{NMR}(100$ $\mathrm{MHz}, \delta_{\mathrm{C}}$ in ppm): $\delta_{\mathrm{C}} 132.4$ (C-2), 101.4 (C-7), 126.9 (C-8), 147.6 (C-12), 126.9 (C-13), 55.0 (C-16), 127.6 (C-20), 172.8 (C-22), 56.5 (CH-3), 64.2 (CH-5), 111.7 (CH-9), 120.9 (CH-10), 103.1 (CH-11), 29.4 (CH-15), 119.9 (CH-19), $19.0\left(\mathrm{CH}_{2}-6\right), 27.7\left(\mathrm{CH}_{2}-14\right), 62.2\left(\mathrm{CH}_{2}-17\right), 64.0\left(\mathrm{CH}_{2}-21\right), 12.1$ $\left(\mathrm{CH}_{3}-18\right), 32.9\left(\mathrm{CH}_{3} \mathrm{~N}-1\right), 48.7\left(\mathrm{CH}_{3} \mathrm{~N}-4\right), 55.3\left(\mathrm{CH}_{3} \mathrm{O}-12\right), 52.8\left(\mathrm{CH}_{3} \mathrm{O}-22\right)$.

\section{Results and Discussion}

The selection of the two-phase solvent system is the most important and critical step in performing HSCCC. One rule for HSCCC mentioned in the literature [16] was the need to find systems with $K^{\prime}$ (partition coefficient) values of the target compounds in a proper range: the suitable $K$ 'values for HSCCC are $0.5 \leq K \leq 1.0$. In the present study, the suitable solvent system for HSCCC separation was developed according this rule considering the properties of the target compounds (monoterpenic indole alkaloids). Thus $\mathrm{CHCl}_{3}-\mathrm{MeOH}-\mathrm{H}_{2} \mathrm{O}$ with different volume ratios were tested for HSCCC separation of these compounds.

A series of experiments was performed to determine a suitable two-phase solvent system for HSCCC [17]. Small amounts of the $\mathrm{MeOH}$ fraction $(5 \mathrm{mg}$ ) were dissolved in $5 \mu \mathrm{L}$ of two immiscible liquid phases consisting of organic solvents and water. From this mixture, $1.5 \mu \mathrm{L}$ of the upper phase and $1.5 \mu \mathrm{L}$ of the lower phase were spotted onto TLC plates and eluted with a solvent system containing organic solvents and water [17]. After elution, plates were dried and observed under UV light $(254 \mathrm{~nm})$ and revealed with sulfuric vanillin and Dragendorff reagents in order to compare the intensity of the spots containing alkaloids in each phase. TLC analyses allowed estimation of the distribution of the alkaloids between the two phases. A 5:10:6 (v/v/v) mixture of $\mathrm{CHCl}_{3}-\mathrm{MeOH}-\mathrm{H}_{2} \mathrm{O}$ gave the best results, with the alkaloids of interest being almost equally distributed between the two phases (partition coefficient value $K$ of approximately 1). A good chromatographic resolution was obtained with the lower phase of this solvent system, with $R_{\mathrm{F}}$ values of 0.7 and 0.6 for compounds 1-2, respectively. The relatively high proportion of $\mathrm{MeOH}$ in the solvent mixture and the $R_{\mathrm{F}}$ values of the compounds indicate the medium or high polarity of the $T$. catharinensis alkaloids. Thus the lower phase was chosen as mobile phase and the upper phase was used as stationary phase for the CCC separation of the $\mathrm{MeOH}$ fraction of the methanolic extract of T. catharinensis. Under the conditions used, the retention of the stationary phase in the HSCCC was $82 \%$. After the HSCCC separation, the collected fractions were monitored by UV-detector $(300 \mathrm{~nm})$ and combined based on TLC. Spectroscopic analyses allowed us to identify two main compounds, identified by comparison with literature data $[18,19]$ as voachalotine (1) and 12-methoxy- $N_{\mathrm{b}}$-methylvoachalotine (2) (Figure 1) $[20,21]$. The identity and purity of the isolated compounds were also checked by TLC analyses using authentic samples from a collection of our laboratory. The alkaloid voachalotine (1) was isolated with 
purity approximately 95\%, whereas 12-methoxy- $N_{\mathrm{b}}$-voachalotine (2) was obtained with purity approximately $97 \%$. The purity of the alkaloids 1 and 2 was also confirmed by CG/MS (Figure 2).

Figure 1. Structure of the isolated alkaloids: voachalotine (1) and 12-methoxy- $N_{\mathrm{b}^{-}}$ methylvoachalotine (2).
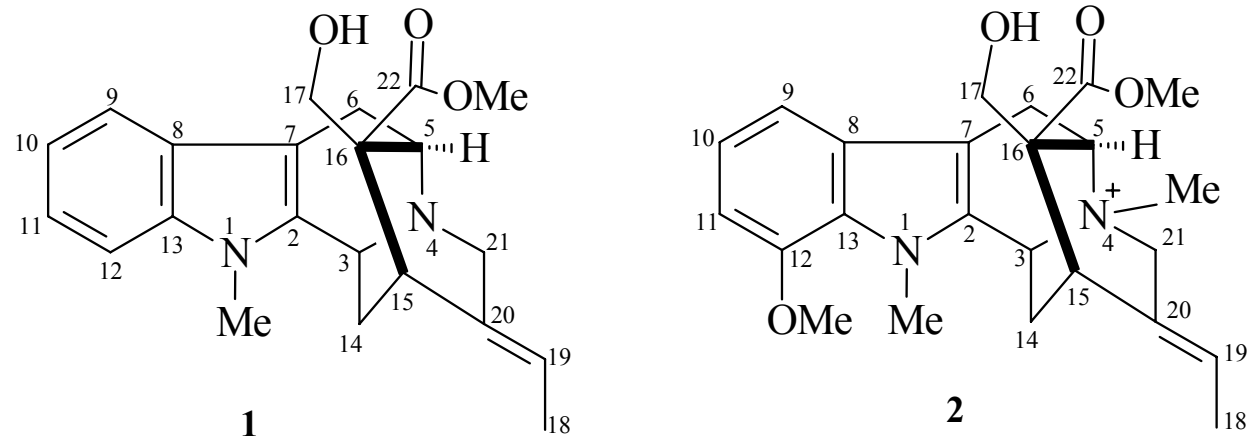

Figure 2. CG of alkaloids voachalotine (1) and 12-methoxy- $N_{\mathrm{b}}$-methylvoachalotine (2).
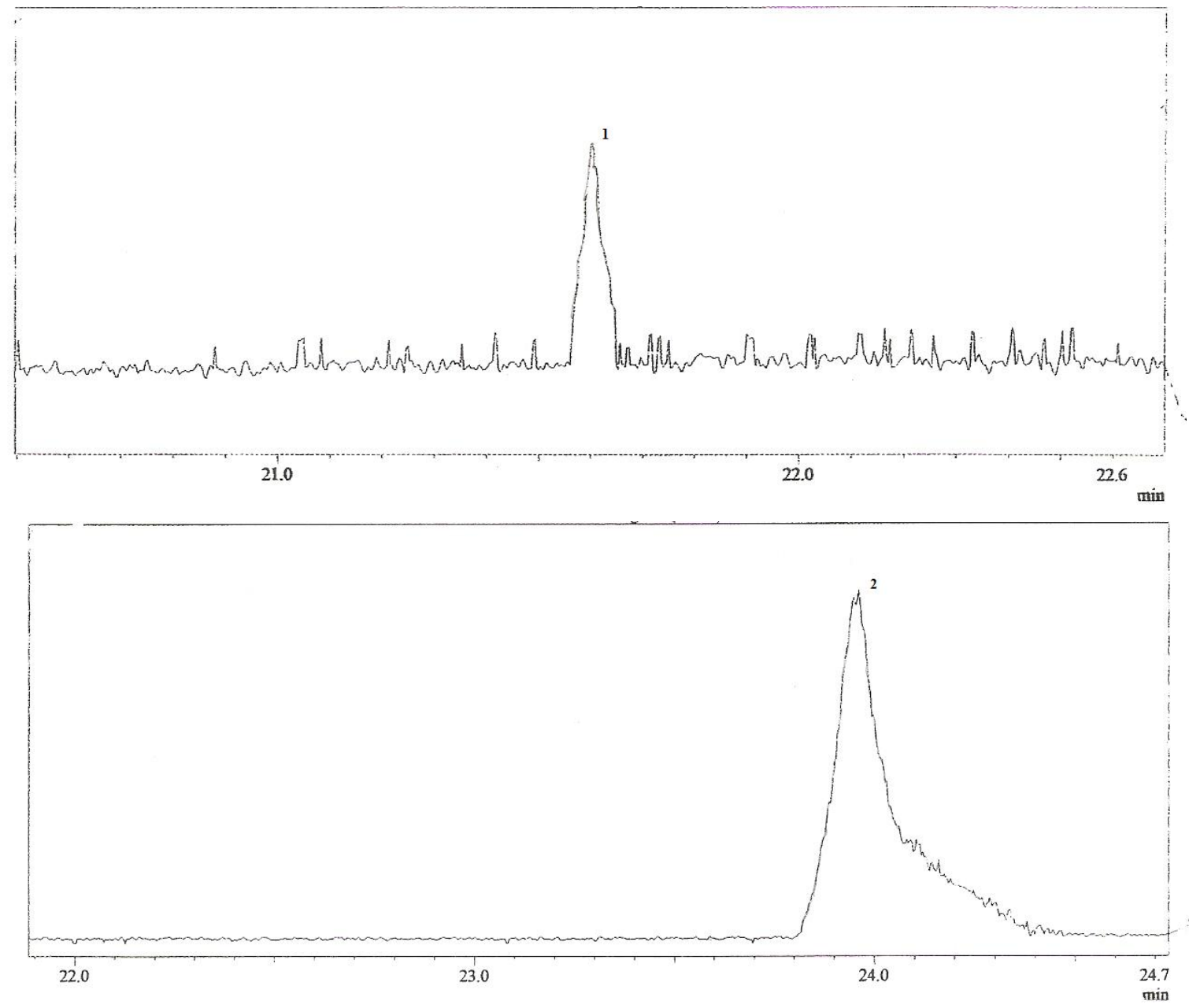

Figure 3 shows the TLC analysis of the purified fractions from the HSCCC separation of fraction 12 of the $\mathrm{MeOH}$ extract of $T$. catharinensis roots: voachalotine (1, fractions 90-124) and 12-methoxy- $N_{\mathrm{b}^{-}}$ methylvoachalotine (2, fractions 164-186). TLC silica gel plates were eluted in $\mathrm{CH}_{2} \mathrm{Cl}_{2}-\mathrm{MeOH}$ 
$(9: 1(v / v))$ and the chemical detection was done by spraying sulfuric vanillin (a) and Dragendorff reagents $(\mathbf{b})$.

Figure 3. TLC monitoring of fractions from the HSCCC separation of fraction 12 from silica gel chromatography of the $\mathrm{MeOH}$ extract of $T$. catharinensis roots: voachalotine (1) (fractions 90-124) and 12-methoxy- $N_{\mathrm{b}}$-methylvoachalotine (2) (fractions 164-186). TLC silica gel plates were eluted in $\mathrm{CH}_{2} \mathrm{Cl}_{2}-\mathrm{MeOH}(9: 1(v / v))$ and the chemical detection was done by spraying sulfuric vanillin (a) and Dragendorff reagents (b).

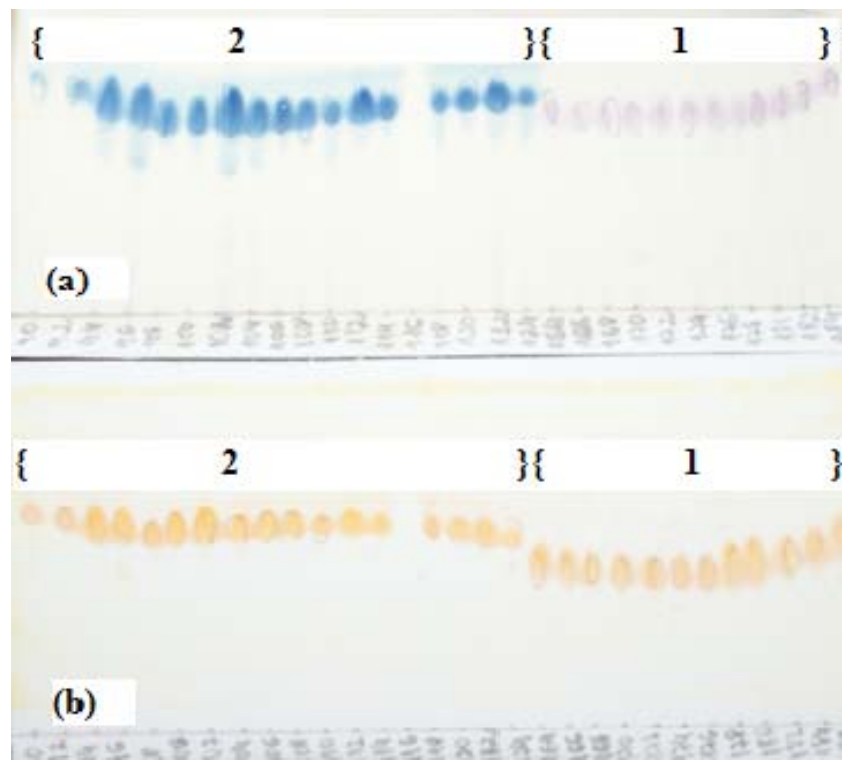

This approach led to the isolation of the two alkaloids in approximately $4.0 \mathrm{~h}$. The alkaloid 12-methoxy- $N_{\mathrm{b}}$-methylvoachalotine (2) was the first compound to be eluted (after $2.4 \mathrm{~h}$ ), because of its lower polarity compared to voachalotine (1). Thus, the separation of these alkaloids seems to depend on the methoxyl group attached to the benzene ring and the methyl group attached to the nitrogen atom at position 4 in alkaloid 12-methoxy- $N_{\mathrm{b}}$-methylvoachalotine (2). Our results showed that the conditions used provided a very efficient method for the separation of the alkaloids from $T$. catharinensis roots.

Preliminary assays with alkaloid 12-methoxy- $N_{\mathrm{b}}$-methylvoachalotine (2) exhibited a significative anti acetylcholinesterase effect (results not shown). Since 1-2 were obtained in good amounts and purity, without the need of further steps of purification, we can conclude that the HSCCC conditions used in our work fits well with our objective of obtaining these compounds to perform future acetylcholinesterase inhibitors tests.

\section{Conclusions}

The results of our studies clearly demonstrate the potential of HSCCC for the preparative isolation of voachalotine (1) and 12-methoxy- $N_{\mathrm{b}}$-methylvoachalotine (2) from the roots of $T$. catharinensis. In particular, preparative HSCCC with its rapid separation and minimum solvent consumption offers a very efficient method for the separation and purification of monoterpenic indole alkaloids. 


\section{Acknowledgments}

The authors are grateful to Fundação Carlos Chagas Filho de Amparo à Pesquisa do Rio de Janeiro (FAPERJ), Consenho Nacional de Desenvolvimento Científico e Tecnológico (CNPq) and Coordenação de Aperfeiçoamento de Pessoal de Nível Superior (CAPES) for scholarships and financial support.

\section{Conflict of Interest}

The authors declare no conflict of interest.

\section{References and Notes}

1. Leeuwenberg, A.J.M. Tabernaemontana: The Old World Species; Royal Botanic Gardens: Kew, UK, 1991.

2. Danielle, B.; Palmisano, G. Alkaloids from Tabernaemontana. In The Alkaloids; Brossi, A., Ed.; Academic Press: Orlando, FL, USA, 1986; Chapter 1, Volume 27, pp. 1-130.

3. Van Beek, T.A.; Verpoorte, R.; Baerheim Svendsen, S.A.; Leeuwenberg, A.J.M.; Bisset, N.G. Tabernaemontana L. (Apocynaceae): A review of its taxonomy, phytochemistry, ethnobotany and pharmacology. J. Ethnopharmacol. 1984, 10, 1-156.

4. Kam, T.S. Alkaloids: Chemical and Biological Perspectives; Pelletier, S.W., Ed.; Pergamon: Amsterdam, The Netherlands, 1999; Chapter 2, Volume 14, pp. 285-435.

5. Kam, T.S.; Sim, K.W. Five new iboga alkaloids from Tabernaemontana corymbosa. J. Nat. Prod. 2002, 65, 669-672.

6. Rates, S.M.K.; Schapoval, E.E.S.; Souza, I.A.; Henriques, A.T. Chemical constituents and pharmacological activities of Peschiera australis. Int. J. Pharmacogn. 1993, 31, 288.

7. Almeida, L.; Cintra, A.C.O.; Veronese, E.L.G.; Nomizoa, A.; Franco, J.J.; Arantes, E.C.; Giglio, J.R.; Sampaio, S.V. Anticrotalic and antitumoral activities of gel filtration fractions of aqueous extract from Tabernaemontana catharinensis (Apocynaceae). Comp. Biochem. Physiol. Pt. C 2004, 137, 19-27.

8. Pereira, C.G.; Leal, P.F.; Sato, D.N.; Meireles, M.A.A. Antioxidant and antimycobacterial activities of Tabernaemontana catharinensis extracts obtained by Supercritical $\mathrm{CO}_{2}+$ cosolvent. J. Med. Foods 2005, 8, 533-538.

9. Pereira, P.S.; Dias, D.A.; Sampaio, S.V.; França, S.C.; Toldo, M.P.A.; Albuquerque, S. Trypanocidal activity from Tabernaemontana catharinensis A.DC. (Apocynaceae). In IIWOCMAP Congress Medicinal and Aromatic Plants. Part 2: Pharmacognosy, Pharmacology, Phytomedicine, Toxicology; Martino, V.; Cafini. N.; Lappa A.; Eds.; ISHS: Mendonza, Argentina, 1999.

10. Delorenzi, J.C.; Attias, M.; Gattass, C.R.; Andrade, M.; Rezende, C.M.; Pinto, A.C.; Henriques, A.T.; Bou-Habib, D.C.; Saraiva, E.M. Antileishmanial activity of indole alkaloid from Peschiera australis. Antimicrob. Agents Chemother. 2001, 45, 1349-1354. 
11. Soares, D.C.; Pereira, C.G.; Meireles, M.A.A.; Saraiva, E.M.B. Anti-Leishmania amazonensis activity of supercritical $\mathrm{CO}_{2}+$ ethanol extracts from Tabernaemontana catharinensis. Rev. Inst. Med. Trop. S. Paulo 2003, 45, 110.

12. Gonçalves, M.S. Constituintes Químicos de Tabernaemontana catharinensis (Apocynaceae). MSc. Thesis, Universidade Estadual do Norte Fluminense: Campos dos Goyacazes, Brazil, 2011, p. 246.

13. Ito, Y. Golden Rules and Pitfalls in Selecting Optimum Conditions for High-Speed CounterCurrent Chromatography. J. Chromatogr. A 2005, 1065, 145-168.

14. Ito, Y. High-speed countercurrent chromatography. CRC Crit. Rev. Anal. Chem. 1986, 17, 65-143.

15. Du, Q.Z.; Jerz, G.; Waibel, R.; Winterhalter, P. Isolation of Dammarane Saponins from Panax notoginseng by High-Speed Counter-Current Chromatography. J. Chromatogr. A 2003, 1008, 173-180.

16. Yochiro, I. Golden rules and pitfalls and selecting optimum conditions for high-speed countercurrent chromatography. J. Chromatogr. A 2005, 1065, 145-168.

17. Hostettmann, K.; Hostettmann, M.; Marston, A. Isolation of Natural Products by Droplet CounterCurrent Chromatography and Related Methods. Nat. Prod. Rep. 1984, 1, 471-481.

18. Lounasmaa, M.; Tolvanen, A. ${ }^{1}$ H-NMR Data of Monoterpenoid Indole Alkaloids. Heterocycles 1986, 24, 3229-3281.

19. Braga, R.M.; Reis, F.A.M. Quaternary Alkaloids from Peschiera fuchsiaefolia. Phytochemistry 1987, 26, 833-836.

20. Gower, A.E.; Pereira, B.S.; Marsaioli, A.J. Indole alkaloids from Peschiera campestris. Phytochemistry 1986, 25, 2908-2910.

21. Pereira, P.S.; França, S.C.; Oliveira, P.V.A.; Breves, C.M.S.; Pereira, S.I.V.; Sampaio, S.V.; Nomizo, A.; Dias, D.A. Chemical constituents from Tabernaemontana catharinensis root bark: A brief NMR review of indole alkaloids and in vitro cytotoxicity. Quím. Nova 2008, 31, 20-24.

Sample Availability: Samples of the alkaloids voachalotine (1) and 12-methoxy- $N_{\mathrm{b}}$-methylvoachalotine (2) are available from the authors.

(C) 2011 by the authors; licensee MDPI, Basel, Switzerland. This article is an open access article distributed under the terms and conditions of the Creative Commons Attribution license (http://creativecommons.org/licenses/by/3.0/). 